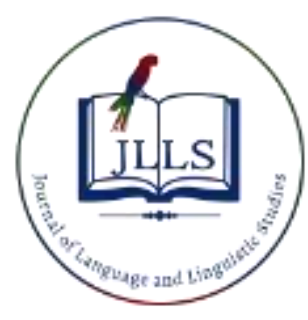

Available online at www.jlls.org

JOURNAL OF LANGUAGE AND LINGUISTIC STUDIES

ISSN: $1305-578 \mathrm{X}$

Journal of Language and Linguistic Studies, 16(2), 552-564; 2020

\title{
The needs of adult immigrants in Europe for social inclusion through language
} education \author{
İsmail Hakk1 Mirici a 1 (iD \\ APA Citation: \\ ${ }^{a}$ Hacettepe University, Ankara, Turkey \\ Mirici, İ.H. (2020). The needs of adult immigrants in Europe for social inclusion through language education. Journal of Language and \\ Linguistic Studies, 16(2), 552-564. \\ Submission Date:09/05/2020 \\ Acceptance Date:23/05/2020
}

\begin{abstract}
Learning the language of the host country plays a significant role in the social life of migrants regardless of their age, gender or cultural background since it is the key to their integration into different dimensions of the social life from the labour market to education or simple daily interactions. This multi-dimensional integration may give rise to a socially cohesive and productive society. The study aimed to investigate the needs of adult immigrants in Europe for their social inclusion through language education. It was based on the survey method and adopted the qualitative research design. For this purpose, the data were collected via a structured questionnaire and a detailed review of literature. For the data analysis, after the pre-analysis, the coding system was administered. The results have revealed that learning the official language at a basic level is not enough for adult immigrants to integrate into the host society; they are actually in need of a comprehensive and multidisciplinary language teaching program comprising both in-class and out of class activities for real engagement and some personal experience in everyday situations in the new socio-cultural environment.
\end{abstract}

C 2020 JLLS and the Authors - Published by JLLS.

Keywords: adult immigrants; European society; social inclusion; language teaching program; multidisciplinary program; socio-cultural engagement

\section{Introduction}

Today migration to western countries, especially to Europe, is an inevitable reality of the underdeveloped or developing countries due to various socio political or/and economic reasons. According to a report (Eurostat, 2017) on migration and migrant population statistics a total of 4.7 million people immigrated to one of the EU-28 Member States during 2015. Among these 4.7 million people about 2.4 million immigrants were the citizens of non-member countries. The first three largest groups of new citizens in the EU Member States in 2015 were citizens of Morocco (10.2\% of all citizenships granted), followed by citizens of Albania (5.7\%) and Turkey (4.2\%). Regarding the gender distribution of immigrants to the EU Member States in 2015, men were $56 \%$ and women $44 \%$. The median age of these immigrants was 27.5 years. Germany reported the largest total number of

\footnotetext{
${ }^{1}$ Corresponding author. Tel.: +90-312-297-8575

E-mail address: hakkimirici@gmail.com
} 
immigrants in 2015, followed by the United Kingdom, France, Spain and Italy. This means these people make one of the biggest European countries their home country despite several kinds of challenges, all of which are related with their adaptation and integration in to their new socio cultural environment. This also means that since it is the official language of their new country, majority of the immigrants are in need of learning one of the most widely used languages in Europe.

Today an increasing number of European countries require adult migrants to demonstrate proficiency in the official language of the host country before granting entry, residence or work permits or citizenship. Language training is often available although the conditions vary.

The Council of Europe organised two conferences, one on 26 and 27 June 2008 and the other on 24 and 25 June 2010, about the linguistic integration of adult migrants in Europe. The level of proficiency required varies depending on the administrative situations namely, admission to the country (A), permanent residence (B) or acquisition of citizenship (C). Commonly the proficiency level required is usually the level of Basic Users (A1, A2l) and Independent User (B1) according to the descriptors of the Common European Framework of Reference for Languages (CEFR) (Extramiana \& Van Avermaet, 2011). However, there are may be millions of them that have already entered the country and received residence or work permit without any evidence of language proficiency. Furthermore, there are hundreds of thousands disadvantaged migrants staying at home and relying on their husband or children without any social integration into life of the host culture due to their inefficiency in communicating with people in the streets or in the real social life. Even more and most importantly, they prepare their children at home for the social life before they reach the school age and before they are socialised with other children in the host culture. The first teachers are the families for children, and these families need to be good teachers and good models for them in order to create a healthy society (Nagel \& Bacon, 2010).

Being able to speak the local language is an important factor for migrants to communicate and function in local society. In addition, learning the local language is an indicator to the general public of the migrants' willingness to integrate and it helps migrants to find employment and to develop an understanding of the local society culture and values (European Commission, 2011a). However majority of the EU citizens (almost 70\%) support "a common European policy on migration" and they have negative feelings about the immigration of people from outside the EU (European Commission, 2016). Consequently, it is safe to claim that language programs for adult immigrants should enable them to become true members of the host society rather than aliens using the official language of the host country in order to satisfy some simple personal needs.

Daily life comprises various socio cultural activities such as music, art, sport, wedding, funeral, birthday, shopping, visiting museum, transportation, etc. An adult immigrant needs to take active part in all these activities without the fear of being rejected. In other words, he/she needs to feel himself/herself as a respected member of the new social environment through interacting in it, and developing a positive attitude towards it. Solely speaking the language of the host society may not be enough for an adult immigrant to set up healthy communication and to develop intercultural understanding in the host society representing different cultural elements. He/she needs to know many other components of daily life. An adult immigrant needs to internalise those new socio cultural behaviours to feel himself/herself as part of the new society to be able to better understand the expected relationship among individuals in the new society. Only in this way he/she may be integrated into the host culture and they may be a good role model for their children as the next generation of the immigrant family in the host country. 


\section{Method}

The study, adopting the qualitative research design, was based on the survey method, and the data were collected in order to determine the needs of adult immigrants in Europe for social inclusion via language education. In the study, a structured questionnaire and the related literature such as official report documents released by the Council of Europe, the European commission, and the like were made use of. The questionnaire was developed by the researcher and was finalised in four sections in accordance with experts' opinions. The first section was about some demographic information; the second part focused on adult immigrants' language learning needs, their preference of material types and the ways of engagement in learning activities, the benefits (if any) they might derive from these activities; in the third part the participants were given an open ended question to describe their understanding of social inclusion and their obstacles in their everyday life in the new social environment; and in the last section they were invited to reflect upon their proficiency level in the target language in accordance with the descriptors in the Self-assessment Grid of the CEFR (Council of Europe, 2011). The questionnaire was administered in 2018 by contact colleagues in each country context namely; England, Latvia, Poland and Turkey. The local colleagues who helped with the questionnaire translated it into the languages of understanding for the participant immigrants. When needed, they also helped the respondents to comprehend the vague statements. Finally, they translated the open ended answers into English before they sent them back to the researcher. In the data analysis process, once the responses of the interviewees were repetitive, the analysis process was finalised, and the data obtained were reported (Yıldırım and Şimşek, 2009). In the reporting process, some of the data were illustrated in tables using percentage and frequency, and the rest were pre-analysed, a table of themes and frequency was developed and subsequently, the coding system was adapted. In this part the data were analysed on the basis of a systematic coding, following the approach suggested by Saldaña (2012) in that the data were broken down according to a code list in order to identify relevant patterns. The coded segments were then grouped and synthesised up into more general categories, which in turn got linked to more general themes and theoretical concepts.

\subsection{Research Problem}

Migrant communities are frequently isolated from civil society; this is especially the case for stayat-home spouses whose language skills sometimes are "fossilized" at a very elementary level of communicative skill (European Center for Modern Languages, 2017). The problem statement of this study is; "What are the needs of adult immigrants in Europe for their social inclusion through an effective and comprehensive language education?" Based on this research question the study aimed to determine the communication and adaptation needs of adult immigrants to be able to integrate in to their new sociocultural environment.

\section{Results}

The findings of the data on demographic information can be illustrated as follows (See Table 1): 
Table 1. Demographic information

\begin{tabular}{|c|c|c|c|c|c|c|c|c|}
\hline QUESTIONS & \multicolumn{8}{|c|}{ COUNTRIES } \\
\hline & \multicolumn{2}{|l|}{ Latvia- (N) } & \multicolumn{2}{|c|}{ Turkey- (N) } & \multicolumn{2}{|c|}{\begin{tabular}{|l|} 
England-(N) \\
\end{tabular}} & \multicolumn{2}{|c|}{ Poland-(N) } \\
\hline \multirow[b]{2}{*}{ Your gender } & $\mathrm{M}$ & $\mathrm{F}$ & $\mathrm{M}$ & $\mathrm{F}$ & $\mathrm{M}$ & $\mathrm{F}$ & $\mathrm{M}$ & $\mathrm{F}$ \\
\hline & 3 & 2 & 0 & 5 & 2 & 3 & 1 & 2 \\
\hline Your age & \multicolumn{2}{|l|}{$25-37$} & \multicolumn{2}{|l|}{$23-42$} & \multicolumn{2}{|l|}{$40-42$} & \\
\hline \multirow[t]{3}{*}{ Your educational background } & Secondary S. & 2 & $\begin{array}{c}\text { Secondary } \\
\text { S. }\end{array}$ & 4 & \multicolumn{2}{|c|}{ University } & \multicolumn{2}{|l|}{ High S. } \\
\hline & High S. & 2 & \multirow[b]{2}{*}{ University } & \multirow[b]{2}{*}{1} & \multirow{2}{*}{\multicolumn{2}{|c|}{5}} & \multirow[b]{2}{*}{ University } & \multirow[b]{2}{*}{1} \\
\hline & University & 1 & & & & & & \\
\hline \multirow{2}{*}{$\begin{array}{l}\text { Marital status } \\
\text { Married: M. } \\
\text { Single : Sgl. }\end{array}$} & M. & Sgl. & M. & Sgl. & \multicolumn{2}{|l|}{ M. } & M. & Sgl. \\
\hline & 5 & 0 & 4 & 1 & \multicolumn{2}{|l|}{5} & 3 & 0 \\
\hline \multirow[t]{3}{*}{ Number of children } & 1 child & 2 & No child & 1 & 1 child & 3 & \multirow[t]{3}{*}{ 1child } & \multirow[t]{3}{*}{3} \\
\hline & 2 children & 2 & 8 children & 1 & \multirow[t]{2}{*}{2 children } & \multirow[t]{2}{*}{2} & & \\
\hline & 3 children & 1 & 9 children & 3 & & & & \\
\hline \multirow[b]{2}{*}{ Your job } & \multirow{2}{*}{\multicolumn{2}{|c|}{ No job }} & Student & 1 & $\begin{array}{l}\text { Business- } \\
\text { man }\end{array}$ & 2 & Self-emp. & 2 \\
\hline & & & Housewife & 4 & Manager & 3 & No job & 1 \\
\hline \multirow[t]{2}{*}{ Country of origin } & \multicolumn{2}{|l|}{ Syria } & \multicolumn{2}{|l|}{ Syria } & \multicolumn{2}{|l|}{ Turkey } & \multicolumn{2}{|c|}{ Vietnam } \\
\hline & \multicolumn{2}{|l|}{5} & 5 & & 5 & & 3 & \\
\hline Your mother tongue & Arabic & & Arabic & & Turkish & & Vietnam & nese \\
\hline & 5 & & 5 & & 5 & & 3 & \\
\hline Host country & Latvia & & Turkey & & England & & Poland & \\
\hline & 5 & & 5 & & 5 & & 3 & \\
\hline Duration in the host country & $2-3$ month & & $3-4.5$ yea & & $\begin{array}{l}7 \text { months- } \\
\text { years }\end{array}$ & & $0.5-3$ yec & \\
\hline
\end{tabular}

As can be seen in the table six of the participants are Male and twelve are Female. Out of these 18 adult immigrants, whose ages range from 23 to 42, six are secondary school graduates, four are high school graduates and eight are university graduates. Therefore it is safe to infer that majority of them did not have a university degree. Except one of them, they are all married and majority with two or more children. Their stay in the host country varies between 2 months to 4.5 years.

The participants' reflection to the questionnaire about their viewpoints concerning their needs for the social inclusion in the new cultural environment are given in the following table (See Table 2): 
Table 2. Needs for social inclusion

\begin{tabular}{|c|c|c|c|c|c|c|c|c|}
\hline \multirow[t]{2}{*}{ QUESTIONS } & \multicolumn{8}{|c|}{ COUNTRIES } \\
\hline & & 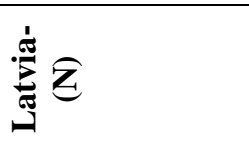 & \multicolumn{2}{|c|}{ 惫忌 } & \multicolumn{2}{|c|}{ 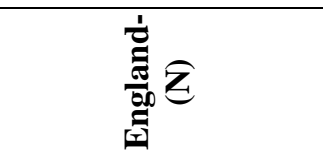 } & \multicolumn{2}{|c|}{ 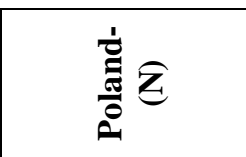 } \\
\hline \multirow{2}{*}{ Course type } & & Both & \multicolumn{2}{|c|}{ Both } & \multicolumn{2}{|c|}{ Both } & Both & $\begin{array}{r}\text { Skills- } \\
\text { based }\end{array}$ \\
\hline & & 5 & \multicolumn{2}{|c|}{5} & \multicolumn{2}{|l|}{5} & 2 & 1 \\
\hline \multirow{2}{*}{$\begin{array}{c}\text { Material } \\
\text { type(s) }\end{array}$} & All & Printed & \multicolumn{2}{|c|}{ All } & \multicolumn{2}{|c|}{ Digital } & Audio & Visual \\
\hline & 4 & 1 & \multicolumn{2}{|c|}{5} & \multicolumn{2}{|c|}{5} & 3 & 3 \\
\hline \multirow[b]{2}{*}{ Content } & \multicolumn{2}{|r|}{ All } & \multicolumn{2}{|c|}{ Writing } & \multicolumn{2}{|l|}{ All } & \multicolumn{2}{|c|}{ Writing } \\
\hline & \multicolumn{2}{|r|}{5} & \multicolumn{2}{|c|}{5} & \multicolumn{2}{|l|}{5} & \multicolumn{2}{|c|}{3} \\
\hline \multirow[b]{2}{*}{ Activities } & \multicolumn{2}{|r|}{ Both } & \multicolumn{2}{|c|}{ Both } & \multicolumn{2}{|c|}{ Both } & \multicolumn{2}{|c|}{ Both } \\
\hline & \multicolumn{2}{|r|}{5} & \multicolumn{2}{|c|}{5} & \multicolumn{2}{|c|}{5} & \multicolumn{2}{|c|}{3} \\
\hline \multirow{2}{*}{$\begin{array}{l}\text { Teaching } \\
\text { method }\end{array}$} & Other & Communicative & No & idea & Structural & No idea & & ther \\
\hline & 4 & 1 & & 5 & 2 & 3 & & 3 \\
\hline & & No idea & No & idea & No id & & 1 year & $1-2$ years \\
\hline Duration & & 5 & & 5 & 5 & & 2 & 1 \\
\hline Contact with & & I want & I want & $\begin{array}{l}\text { I don't } \\
\text { know }\end{array}$ & I wan & & & want \\
\hline & & 5 & 4 & 1 & 5 & & & 5 \\
\hline & $\begin{array}{l}\text { Day } \\
\text { times }\end{array}$ & Flexible & Day times & Flexible & Day tin & nes & Eveni & ng times \\
\hline Class period & 4 & 1 & 1 & 4 & 5 & & & 3 \\
\hline Study type & $\begin{array}{l}\text { With } \\
\text { local } \\
\text { buddy }\end{array}$ & Individual & $\begin{array}{l}\text { With } \\
\text { local } \\
\text { buddy }\end{array}$ & No idea & Individual & $\begin{array}{c}\text { Vith local } \\
\text { buddy }\end{array}$ & Part & nership \\
\hline & 4 & 1 & 4 & 1 & 2 & 3 & & 3 \\
\hline & Formal & All & & 11 & $\begin{array}{c}\text { Self- } \\
\text { assessment }\end{array}$ & All & & ormal \\
\hline Assessment & 4 & 1 & & 5 & 1 & 4 & & 3 \\
\hline
\end{tabular}

As it is seen in the table above, it can be understood that majority of the participants prefer a language program comprising both structure and skills based activities via audio, visual, printed and digital materials. Although they do not have a specific preference about the method or duration of the language program, many of them feel day times are more convenient and having a language buddy or a partner will be beneficial. They are also of the opinion that the assessment should be based on formal, informal and self- assessment tools.

The participants' self-assessment about their own proficiency level in the local language of the host society can be shown as follows (See Table 3): 
Table 3. Data about "proficiency level"

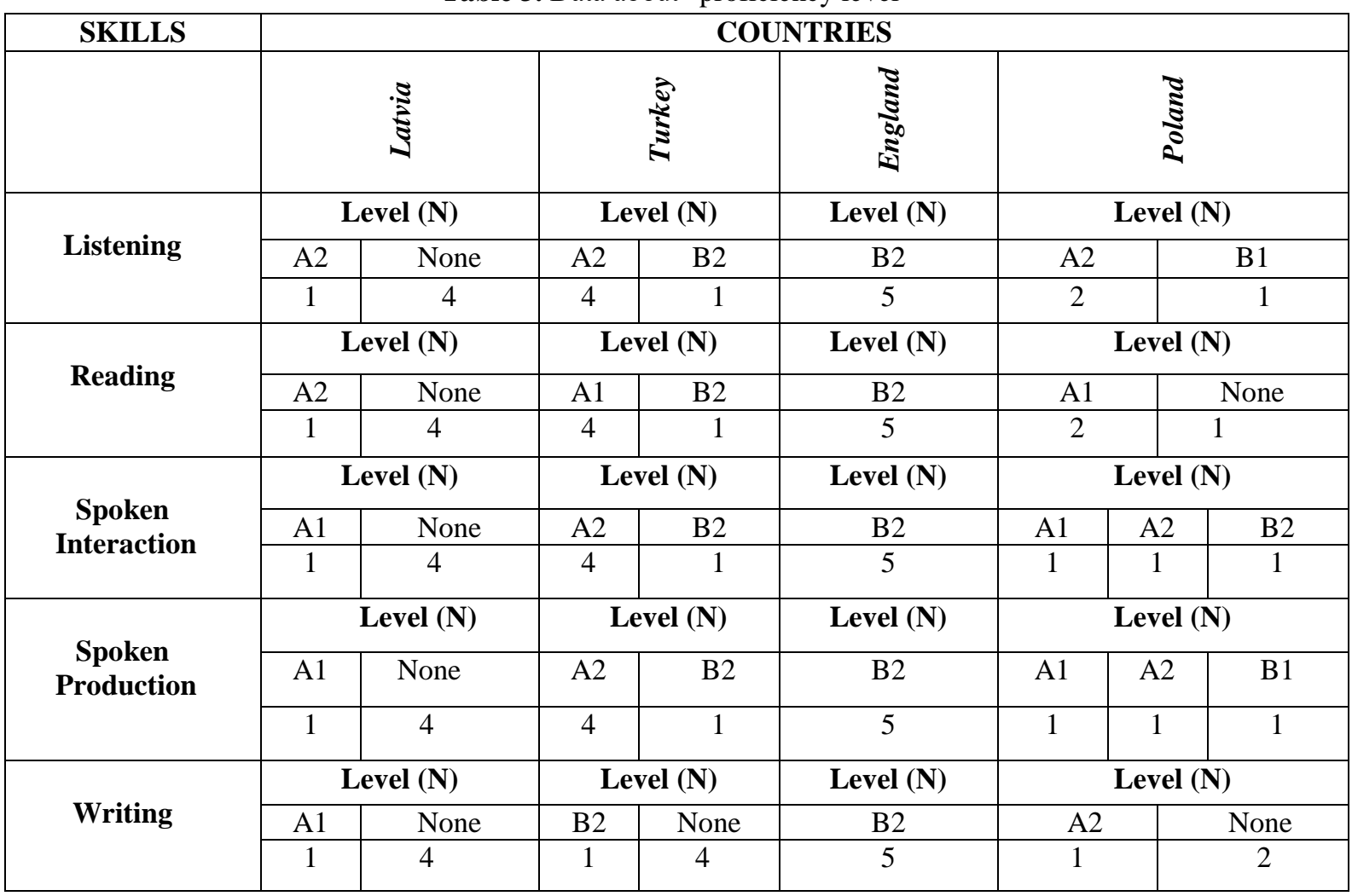

As the table shows the participants' language proficiency level ranges from Basic Users (A level) to Independent Users (B level) in accordance with the CEFR descriptors. Meanwhile it is understood that the alphabet of the migrants influences their proficiency level in writing, in that Arabic and Vietnamese immigrants have lower proficiency level in writing in comparison with the Turkish ones.

Most of the documents released by various European organisations have a common aspect that Europe needs a more cohesive and inclusive society for a more democratic life (Council of Europe, 2005; Council of Europe, 2010; European Commission, 2011b). Education is one of the most effective fields to prevent violent radicalisation by promoting common European values, fostering social integration, enhancing intercultural understanding and a sense of belonging to a community.

As regards the linguistic integration of adult migrants, the Council of Europe provides expertise and good practices for the member states in order to facilitate the implementation of human rights standards as given in paragraph 11 of Article 19 of the European Social Charter (revised)(Council of Europe, 1996):

\section{Article 19 - The right of migrant workers and their families to protection and assistance}

With a view to ensuring the effective exercise of the right of migrant workers and their families to protection and assistance in the territory of any other Party, the Parties undertake:

[1] to promote and facilitate the teaching of the national language of the receiving state or, if there are several, one of these languages, to migrant workers and members of their families;

In keeping with the Warsaw Declaration (Council of Europe, 2005) the Council of Europe Parliamentary Assembly has resolved to focus its activities in the field of migration on, "promoting intercultural dialogue, fostering tolerance and ensuring the integration of immigrant communities in their host societies" (Resolution 1511 (2006), § 4.2). Similarly, according to Resolution 1437 (2005), I.4 of the Parliamentary Assembly of the Council of Europe, host societies have to respect immigrants' dignity and distinct identity and to take them into account when forming domestic policies. Besides, it 
has also elaborated standard setting instruments and recommendations in the migration field complemented by language policy guidelines and reference tools to promote effective implementation in an inclusive approach based on shared values and principles (Council of Europe, 2014).

Current European policies in the field of adult education and training provide opportunities for adults to learn from each other. These policies cover such common challenges as the recognition of skills and abilities gained not only inside but also outside of the classroom settings. For this purpose, integrated multidisciplinary programs with the Education, Training, and Sport sectors are promoted and supported (European Commission, 2011b). To illustrate, the Council of Europe aims to ensure respect for human rights, democracy and the rule of law. All its actions are designed in order to provide social inclusion, social cohesion and respect for diversity (Council of Europe, 2010; Beacco et al, 2017).

When the participants' responses to the open-ended question in the third part of the questionnaire are considered, it is understood that the adult immigrants have various expectations and obstacles in the host society. Their expectations are categorised as "finding a good job or improving their job", "having a social status", "having a better education", "establishing a better life for the future", "receiving support from the local people" as well as "from their family members". The obstacles they may face are also categorised as "lack of communication skills", "lack of contact with the local people", "inadequate personal effort", "more contact with fellow citizens", "time constraints", "their work load", "lack of self-confidence" and "lack of socio-cultural activities in the host culture". The findings based on the analysis of the qualitative data are given in the following table (Table 4).

Table 4. Expectations and obstacles in terms of social inclusion

\begin{tabular}{|c|c|c|c|c|}
\hline & Categories & \begin{tabular}{|l|}
$\begin{array}{l}\text { Response } \\
\text { record } \\
(\mathrm{N}=18)\end{array}$ \\
\end{tabular} & $\begin{array}{c}\text { Total } \\
\text { records } \\
(\%) \\
\end{array}$ & Some Sample Reflections \\
\hline \multirow{6}{*}{ 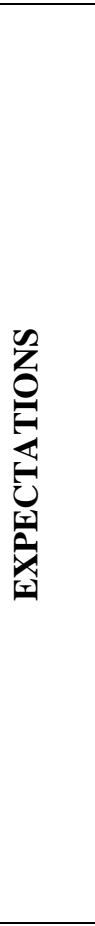 } & $\begin{array}{l}\text { To find a good job or } \\
\text { improve the job }\end{array}$ & 5 & 33.33 & $\begin{array}{l}\text { - I need the language mostly for job purposes } \\
\text { (running a shop). } \\
\text { - I would like to have a steady job, now I help } \\
\text { people clean houses and help my family with } \\
\text { their business. } \\
\text { - I will definitely want to learn more language, } \\
\text { because then I will be able to find a better job, } \\
\text { or maybe start my own business. }\end{array}$ \\
\hline & To have a social status & 2 & 13.33 & $\begin{array}{l}\text { - I want to become a citizen. } \\
\text { - I want to have a higher status. }\end{array}$ \\
\hline & For better education & 4 & 26.66 & $\begin{array}{l}\text { - I would also like to go to a language course and } \\
\text { maybe go to university and finish my education. } \\
\text { - I need to complete my education. }\end{array}$ \\
\hline & $\begin{array}{l}\text { Establishing a future } \\
\text { life }\end{array}$ & 5 & 33.33 & $\begin{array}{l}\text { - Maybe I will stay here for a long time, maybe } \\
\text { not, I haven't decided yet. } \\
\text { - I have no expectation. I want to go back my } \\
\text { country }\end{array}$ \\
\hline & Support from the local & 4 & 22.22 & $\begin{array}{l}\text { - I want my expectations to be considered. } \\
\text { - They should help me improve my language. }\end{array}$ \\
\hline & $\begin{array}{l}\text { Support from the } \\
\text { family members }\end{array}$ & 4 & 22.22 & $\begin{array}{l}\text { - My daughter starts school this year, so maybe } \\
\text { she will have more local friends and we will } \\
\text { have contacts with them as well. }\end{array}$ \\
\hline$\sum_{\substack{\bigcup_{0} \\
0}}^{\infty}$ & Communication skills & 5 & 33.33 & $\begin{array}{l}\text { - My language proficiency is not very high, but I } \\
\text { can communicate well. } \\
\text { - I would like to live and speak the language } \\
\text { without hesitation. } \\
\text { - I am interested in sense of humour. }\end{array}$ \\
\hline
\end{tabular}




\begin{tabular}{|c|c|c|c|}
\hline Contact with the local & 3 & 20 & $\begin{array}{l}\text { - I would like to contact with local people, but it } \\
\text { will be hard. } \\
\text { - I want to feel and understand how their } \\
\text { language is flexible. }\end{array}$ \\
\hline $\begin{array}{l}\text { Contact with fellow } \\
\text { citizens }\end{array}$ & 5 & 33.33 & $\begin{array}{l}\text { - We have a small community of people here } \\
\text { (family and friends), so out of work I speak my } \\
\text { mother tongue. } \\
\text { - We all would like to go back our country back } \\
\text { once the war ends. }\end{array}$ \\
\hline Time constraints & 2 & 13.33 & $\begin{array}{l}\text { - I am busy with my work, so I don't have much } \\
\text { time for friendships or close relationships with } \\
\text { the local. }\end{array}$ \\
\hline $\begin{array}{l}\text { Lack of self- } \\
\text { confidence }\end{array}$ & 2 & 13.33 & $\begin{array}{l}\text { - My language proficiency is very limited, so my } \\
\text { wife mostly talks to the clients. I would like to } \\
\text { learn more but probably it will be difficult. } \\
\text { - I do not want to feel excluded. }\end{array}$ \\
\hline
\end{tabular}

The result of the Chi-Square test analysis related to the "Expectations" and "Obstacles" of the participants are given as follows (See Table 5).

Table 5. Comparisons of expectations and obstacles in terms of social inclusion

\begin{tabular}{ccc}
\hline Test Statistics & EXPECTATIONS & OBSTACLES \\
\hline Chi-Square & $1.500^{\mathrm{a}}$ & $2.706^{\mathrm{a}}$ \\
Df & 5 & 4 \\
Asymp. Sig. & .913 & .608 \\
\hline
\end{tabular}

The table shows that there is no significant difference among the categories of the "Expectations" $\chi^{2}(5)=1.5, p=.913$. Similarly, there is no significant difference among the categories of the "Obstacles" $\chi^{2}(4)=2.706, p=.608$.

As is seen from the results of the data analyses, for a true social inclusion in Europe, adult immigrants are in need of receiving a language education composed of both in class studies and out of class experiences in the real life situations. According to reflections of the adult immigrants it is realised that in an effective program language should not be considered as a lesson to study or memorise but a vehicle for communication to be able to integrate into social life as a natural part of the society one belongs to.

\section{Discussion and Conclusions}

The social inclusion problems of adult immigrants in Europe seem to be common (Arslan, 2019; Stathopoulou and Dassi, 2020). Therefore, the solution methods to these problems should also be common. It may be practical and feasible for curriculum designers to work together with academics and governmental authorities from different European contexts in order to set up strategies and to develop problem solving tools in a cooperative way. This kind of an approach may contribute to the achievement of the European policy in terms of linguistic and socio-cultural inclusion of adult immigrants.

The Common European Framework of Reference for Languages: Learning, teaching, assessment (CEFR) recommends adopting an "action oriented approach" for an effective language teaching program (CoE, 2011). The "action" in this approach requires natural use of the language for one's 
personal communication needs in the heart of the life. However, as offered in many European contexts, learning the language of the host society at a basic level (A1 or A2) does not mean integration into a new social environment because A1 or A2 level of language users (Basic users) cannot communicate properly. The language programs offered to adult immigrants in Europe should have a diverse component comprising linguistic, communicative and socio-cultural elements both inside and outside of the classroom settings in order to enable them to become independent and confident users of the target language. In other words; an effective and comprehensive language program should consider the needs of the adult immigrants in terms of linguistic, communicative and intercultural components; planning recreational and socio-cultural elements of the language program for the adult immigrants as the significant components of socialisation and self-care in the host society because what they need are;

Effective language teaching/learning procedures in accordance with the principles of the Common European Framework of Reference for Languages (CEFR) (Council of Europe, 2017) promoting the use of the European Language Portfolio (ELP) as a self-assessment tool for linguistic and intercultural experiences and attainments (Little, 2009).

A language program aiming to have the adult immigrants attain at least Independent User (B1/B2) level of competence of the CEFR in all language skills (listening, reading, spoken interaction, spoken production and writing) ) (Extramiana \& Van Avermaet, 2011).

Social, cultural, recreation and art oriented out of class activities under the supervision of a buddy from the host society as a reliable language partner to practice the language in real life as an independent, respected and active member of the new society.

Collaboration among experts from the field of language education, educational administration, adult education, social and professional integration can be effective to achieve the desired goal.

In the new era of education, skills and competences are not developed only in the formal learning setting of a classroom but more and more outside of a classroom. Especially for adults, important learning takes place at work, through participation in social life or interaction with peers. When the needs of adult immigrants in Europe are considered it can be understood they besides language, they need to develop their other competencies such as communicative, intercultural as well as general personal competencies (independent learning, adopting new environment, etc.). Therefore, language teaching programs should be planned in a holistic manner comprising some in-class teaching practices, some out of class socio-cultural activities and even some personal development facilities such as sport and art in the heart of the host society. Specific course materials composed of textbooks, visuals, audios and videos specifically reflecting contextual settings based on the domains of the real life situations can be useful for such a purpose.

The needs of adult immigrants for social inclusion can also be met through such a language program that it is designed through a cross-sectoral international cooperation among governmental organisations, universities, cultural centres in Europe towards mutually beneficial results and outcomes. The implementations should focus on a coherent and comprehensive set of interconnected activities which are flexible and have potential to be adaptable to current and future contexts and developments across Europe. The program and the materials developed should be used commonly by every European institution. In addition, when desired, these documents and the program model should also be flexible enough to be adapted into any other European languages, too. Thus it will contribute to sort out language and social inclusion problems of adult immigrants living in different European countries speaking different European languages.

It is important that the program be based on the CEFR's "action oriented approach" requiring both in class and out of class activities comprising linguistic, social and cultural involvement. The curriculum designers may work on the principles and the outline of the language program considering the needs of 
the adult immigrants as well as of the society they are the new members; then the materials may be developed and the program may be implemented. It can be recommended that the effectiveness of the program be evaluated, and if successful, be disseminated. In this way a multidisciplinary language program can be planned and designed in order to enable adult immigrants to develop their communication skills in the language of the host society as well as their social inclusion abilities in the new cultural environment. The goals cannot be achieved through only national, regional or local cooperation because the social inclusion problem in Europe may not be sorted out via a local perspective because adult immigrants are everywhere in Europe (Crul \& Mollenkopf, 2012). It has to be multinational, flexible, multidimensional and multidisciplinary. Some multinational European projects can be helpful to find common solutions to common problems concerning social inclusion of adult immigrants in their new hosting countries.

\section{Ethics Committee Approval}

The author(s) confirm(s) that the study does not need ethics committee approval according to the research integrity rules in their country (Date of Confirmation: May 09, 2020).

\section{References}

Arslan, M. (2019). Educational and integration problems of immigrant Turkish youth in Germany. International Journal of Curriculum and Instruction 11(1), 89-100.

Beacco, J-C, Krumm, H.J., Little, D., Thalgott, P. (2017) (Eds) The Linguistic Integration of Adult Migrants. Walter de Gruyter GmbH: Berlin

Council of Europe. (2005). Warsaw Declaration. Retrieved from http://www.coe.int/t/dcr/summit/20050517 decl varsovie EN.asp

Council of Europe. (2010). EUR-Lex - 52011DC0455 Retrieved from http://eur-lex.europa.eu/legalcontent/EN/TXT/?uri=CELEX:52011DC0455

Council of Europe. (2011). Common European Framework of Reference for Languages: Learning, teaching, assessment. Cambridge: CUP

Council of Europe (2014). Language education policies for adult immigrants. Retrieved from http://www.coe.int/t/dg4/linguistic/MIGRANTS_EN.asp

Council of Europe. (2017). Common European Framework of Reference for Languages. Retrieved from http://www.coe.int/en/web/common-european-framework-reference-languages

Crul, M., Mollenkopf, J. (2012). Eds. The Changing Face of World Cities. New York: Russell Sage Publication

European Center for Modern Languages. (2017) Migration and language education. Retrieved from http://www.ecml.at/Thematicareas/Migrantlanguageeducation/tabid/1624/language/enGB/Default.aspx

European Commission. (2011a). Migrant Integration Aggregate Report. Retrieved from http://ec.europa.eu/commfrontoffice/publicopinion/archives/quali/ql_5969_migrant_en.pdf

European Commission (2011b) Renewed European Agenda for adult learning. Retriewed from http://ec.europa.eu/education/policy/adult-learning_en 
European Commission (2016) Public opinion in the European Union. Standard Eurobarometer 86 Autumn 2016. Retrieved from file:///C:/Users/acer/Downloads/eb86 first en.pdf

Eurostat (2017). Migration and migrant population statistics. Retrieved from http://ec.europa.eu/eurostat/statistics explained/index.php/Migration_and_migrant_population_statistics

Extramiana, C. \& Van Avermaet, P. (2011). Language requirements for adult migrants in Council of Europe member states: Report on a survey. Strasbourg: CoE Language Policy Division

Little, D. (2009). The European Language Portfolio: where pedagogy and assessment meet. 8th International Seminar on the European Language Portfolio, Graz, 29 September-1 October 2009

Nagel, A.D., Bacon, P.A. (2010). Importance of Early Childhood Education: Family Involvement. Early Childhood Education: Birth- 8. New York: Prentice Hall

Saldaña, Johnny (2012): The Coding Manual for Qualitative Researchers (Second Ed.). London: Sage

Stathopoulou, M.; Dassi, P. (2020). Teaching languages to students from refugee and migrant backgrounds around Europe: Exploring difficulties and teachers' beliefs. International Online Journal of Education and Teaching (IOJET), 7(1), 60-82.

Yıldırım, A., Şimşek, H. (2009). Sosyal Bilimlerde Nitel Araştırma Yöntemleri. Ankara: Seçkin Yayıncilik

\section{Appendix A.}

\section{THE QUESTIONNAIRE ABOUT ADULT IMMIGRANTS' NEEDS FOR SOCIAL INCLUSION THROUGH} LANGUAGE EDUCATION

Dear participant,

This questionnaire has been designed to find out your needs for your social inclusion through language education in your host society. This questionnaire is part of a scientific research and the data will only be used within the scope of the study. All your responses are confidential and will not be shared with anyone else. If you decide to withdraw you are free; and after submitting your questionnaire to me if you change your mind and do not want me to use your responses, it will be removed from the research documents. Thank you very much for your contribution to the study and thank you very much for your cooperation.

Please, provide answers for the questions in each section

Researcher

PART A. General Questions

1. Your gender

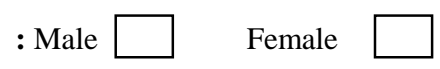

2. Your age

3. Your educational background:

Primary S. High S. Secondary S. University

4. Marital status : Married Single

5. Number of children

6. Your job

7. Country of origin

8. Your mother tongue

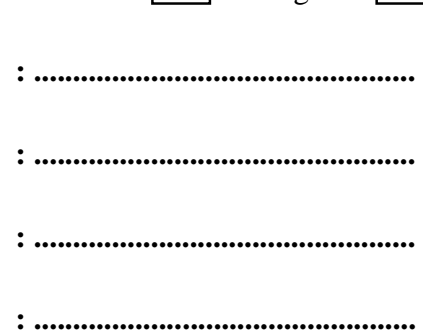




\section{Host country}

10. Duration in the host country :

\section{PART B. Needs for Social Inclusion}
1. Course type
: Grammar based
Skills based $\square$ Both
2. Material type(s)
: Audio $\square$ Visual
Printed $\square$ Digital
3. Content

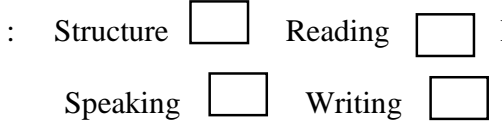
Listening
Speaking
Writing
All

4. Activities

: In class $\square$ Out of class $\square$ Both

5. Teaching method

: $\quad$ Structural $\square$ Communicative $\square$ Other (Please specify )...

6. Duration (Please, specify)

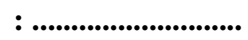

7. Contact with the local

: I want $\square$ I do not want $\square$ Not sure

8. Class period

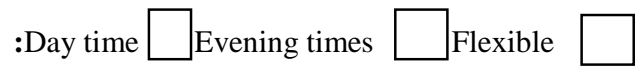

9. Study type

: Individual $\square$ Partnership $\square$ With a local buddy

10. Assessment

: Formal $\square$ Informal $\square$ Self-assessment

All

\section{PART C. Your Expectations and Obstacles in terms of Social Inclusion}

Please, write shortly your expectations and obstacles in terms of "Social Inclusion" in the new social environment. In your statements please specify to become a part of your new social environment What would you like to do?, What would you like to learn?, How would you like to live? 


\section{Avrupa'daki yetişkin göçmenlerin dil eğitimi yoluyla sosyal içerme ihtiyaçları}

\section{$\ddot{O} \mathbf{z}$}

Ev sahibi ülkenin dilini öğrenmek göçmenlerin yaşlarına, cinsiyetlerine veya kültürel geçmişlerine bakılmaksızın sosyal yaşamlarında önemli bir rol oynar, çünkü dil öğrenme işgücü piyasası, eğitim ya da basit günlük etkileşimler gibi sosyal yaşamın farklı boyutlarına uyum sağlamalarının anahtarıdır. Bu çok boyutlu bütünleşme sosyal olarak uyumlu ve üretken bir topluma yol açabilir. Çalışma, Avrupa'daki yetişkin göçmenlerin dil eğitimi yoluyla sosyal katılım ihtiyaçlarını araştırmayı amaçlamıştır. Bu çalışmada anket yöntemine dayanan nitel araştırma tasarımını benimsemiştir. $\mathrm{Bu}$ amaçla veriler yapılandırılmış bir anket ve literatürün ayrıntılı bir şekilde gözden geçirmesi yoluyla toplanmıştır. Veri analizi için, ön analizden sonra kodlama sistemi uygulanmıştır. Sonuçlar, resmi dili temel düzeyde öğrenmenin yetişkin göçmenlerin ev sahibi topluma entegre olmaları için yeterli olmadığını göstermiştir; aslında yeni sosyo-kültürel ortamdaki etkin katılım ve gündelik durumlardaki bazı kişisel deneyimler için hem sınıf içi hem de sınıf dışı etkinlikleri içeren kapsamlı ve çok disiplinli bir dil öğretim programına ihtiyaç duyulmaktadır.

Anahtar sözcükler: yetişkin göçmenler; Avrupa toplumu; sosyal içerme; dil öğretim programı; multidisipliner program; sosyo-kültürel katılım

\section{AUTHOR BIODATA}

İsmail Hakkı Mirici, PhD, is a full time Professor at Hacettepe University, Faculty of Education, ELT Department, Ankara, Turkey. He was also the elected President (2011-2013) of the World Council for Curriculum and Instruction (WCCI), and the Founder of the WCCI Turkish Chapter. He has been lecturing at Turkish universities for about 35 years. He has about 20 books and more than 50 articles published in academic journals. He has coordinated or participated in the steering committees of several national and international education projects. His main fields of studies are English Language Teaching, Teacher Training and Curriculum and Instruction. 